\title{
Developing Learning Model Based on Local Culture and Instrument for Mathematical Higher Order Thinking Ability
}

\author{
Sahat Saragih ${ }^{1}$, E. Elvis Napitupulu ${ }^{1} \&$ Amin Fauzi $^{1}$ \\ ${ }^{1}$ Mathematics Education FMIPA Unimed, Indonesia \\ Correspondence: Sahat Saragih, Jl. Willem Iskandar Psr. V Medan, 20221, Indonesia. E-mail: \\ saragihpps@gmail.com
}

Received: August 30, 2016

Accepted: October 11, $2016 \quad$ Online Published: May 29, 2017

doi:10.5539/ies.v10n6p114

URL: https://doi.org/10.5539/ies.v10n6p114

\begin{abstract}
This research aims to develop a student-centered learning model based on local culture and instrument of mathematical higher order thinking of junior high school students in the frame of the 2013-Curriculum in North Sumatra, Indonesia. The subjects of the research are seventh graders which are taken proportionally random consisted of three public junior high schools with 86 students and two private schools with 40 students. As a Developmental Research, the work is done within three stages. The results obtained in the second stage, both learning tools (books of students, teachers, and students' activities sheet) and research instruments are valid with minor revisions, and the results of the trial showed that the reliability scores of the tests comprising of Comparison (MAT-1), Social Arithmetic (MAT-2), Triangle (MAT-3), Quadrilateral (MAT-4), and Transformation (MAT-5) respectively $0.835,0.588,0.438,0.833$, and 0.908 . The findings showed that the student-centered learning based on local culture model and the instrument for higher order mathematical thinking ability are valid and effective to use in teaching mathematics for junior high school.
\end{abstract}

Keywords: students-centered learning model, local culture, higher order mathematical thinking

\section{Introduction}

Higher order mathematical thinking ability is part of a major vision of mathematics education. The vision stated that mathematics education is devoted to understand the concepts and ideas of mathematics which are then applied in solving routine and non-routine problems through reasoning, communicating, and developing connections within mathematics and beyond. To the extent, students are expected to be creative, have the habit of working hardly and self-contained, be honest, be discipline, have good social attitudes, have self-confidence, and have sense of beauty to the regularity of the nature of mathematics, as well as develop an attitude of open and objective mind indispensable in facing future ever changed.

The vision above is described in mathematical learning objectives proclaimed by the KTSP-Curriculum (2006) and 2013-Curriculum, and in accordance with the recommendation of NCTM (2000), which aims to develop: 1. The ability to solve mathematical problems emerged from real life; 2 . The ability to use mathematics as a tool of communication; 3 . The ability to relate the idea within mathematics; 4 . The ability to reason mathematically in any circumstances, such as critical thinking, logical, and systematic; be objective, honest and disciplined in looking at and solving problems.

Recent studies revealed that high level mathematical thinking skills of junior high school students are still far from adequate. Saragih and Habeahan (2014) showed that student's problem solving ability is low. Some of them were not able to mention what information is given and either it is sufficing or not to solve the problem. Others were not able proposing a plane. The others were neither capable execute strategy chosen nor look-back to their work. Elsewhere, Yuliani and Saragih (2015) reported that private school eight graders students in Medan showed lackness of mathematics critical thinking, almost all of them committed falsity while synthesizing. They failed analyzing the problem, providing incomplete work, and drawing conclusions.

Likewise, another result Saragih and Yusra (2016) found that MTs students of grade VII have low math communication skills. Most of them only answered questions directly, unfocusedly and irreasonably. When asked to explain they cannot express how to get the answers. They only see the existing number and directly add it up. 
The low ability in higher order mathematical thinking indicates that the learning process teachers' conduct has not been able to foster and facilitate students to achieve the vision and goals of mathematics education. Consequently, the learning process needs reform, i.e. the learning paradigm should shift from "teacher-centered" to "student-centered learning".

The changes in the 2013-Curriculum, which is currently being put into effect is a consequence of the reform of learning processes. In fact, from the in-service teachers training (PLPG) which was held from 2007 to 2015 as well as several studies (Saragih 2007, 2009, 2010, 2013), and the last research of Saragih (2015), almost entirely of the teachers conduct learning using teacher-centered paradigm. They begin lecturer by giving explanations or examples on the materials to be covered without associating environmental conditions (real-world contexts) then continue by giving assignments that are similar to the example problems and end with giving homework (tasks). Interaction among students and students to teacher rarely exists. Teacher dominates the teaching and learning process which implies less chance to students to develop themselves through learning that designed to invent concepts. This shows that the teachers do not have knowledge on concept of learning according to the new paradigm that is student-centered.

Some learning approaches that have characteristics consistent with student-centered, among others are problem-based, contextual, realistic, open-ended, problem solving, and so on which should be implemented by mathematics teacher in the classroom. For that purpose, it is truly important to create a learning model together with its devices which enable and foster students improve their imagination and creation. This is in accordance to Cooney (Sumarno, 2005) and Saragih (2015) which encourage initiating classrooms by giving students challenging problem which requires cognitive and metacoginitive strategies, study groups and interactive learning. It requires students to examine, explore, communicate, make conjecture, submit justification, and give argument. The present of contextual non-routine and open problems is expected giving context to students, foster habits to learning the local culture so they will be close and fun to the students. Learning to solve problems based on local culture will create new atmosphere which is exciting and fun and in turn motivate students to learning.

The cultural context can be used as a tool for learning to motivate students to apply mathematical concepts, working in groups, and perceived linkages between the various subjects. This happen because mathematics is a form of culture that is integrated in all aspects of human life (Bishop in Tandililing, 2013). The including mathematics with the culture of mathematics was also stated by Pinxten (Tandililing, 2013) which states that the essence of mathematics is symbolically technology that grows on the skill or activity is cultural environment. Thus it is possible in the presence of the local cultural context on mathematics learning, the meaningful learning process will occur as expected. This is supported by Yusra and Saragih (2016) which reported the existence of positive changes in students' mathematical communication ability, the answering process, and motivation in implementing joyful learning based on Malay culture.

A number of preliminary studies (Saragih, 2007, 2009, 2010, 2013, 2015; Herman, 2006; Suryadi, 2005; Haji, 2005) which implemented student-centered learning with different approaches reported an increased among others in critical think critically, logical thinking, communication skills, reasoning, understanding, mathematics connection, and positive attitude toward mathematics of middle school students. Now arises an interesting and important question to seek resolution, that is how do to develop a student-centered learning model based on local culture and instrument of higher order mathematical thinking? Relating to the problems proposed above, this research aims to develop a student-centered learning model based on local culture and instrument to measure higher order mathematical thinking of junior high school students within 2013-Curriculum in North Sumatera.

\section{Method}

\subsection{Population and Research Sampling}

The research population was all grade VII students in public and private junior high school in North Sumatra. Samples were selected proportionally-random and chosen three public schools and each is represented by one classroom. All of them amount 86 . Two other schools are private and represented by two classrooms of amount 40. Therefore, the students engaged in the research are 126.

\subsection{Data Collection and Analysis}

The data were obtained from varies techniques collection, such as test, questionnaire and observation sheet. The test is used to analyze and validate the level mastery of higher order mathematical thinking. The questionnaire used to determine student response related to the learning processes and mathematical concepts. While the observation sheet used to determine the degree of implementation of the strategy learning model used in the classroom, which in this case relates to the activities of teachers and students in learning. The test has been 
validated by an education expert prior to use outside the classroom first tested the samples, and then analyzed to obtain validity and reliability. Product-moment correlation formula is used to calculate the validity of the test (Sugiyono, 2013). While for counting the readability coefficient, the Alpha formulation is taken (Arikunto, 2009).

\subsection{The Research Approach}

This is a research \& developmental study which orient to product development. Van den Akker (1999) called it formative research that the activities carried out repeatedly (cyclic) and designed and tested a mathematical model of learning material products (Figure 1).

The second phase of research activity is part of three phases of the study. These three stages are described as follows:

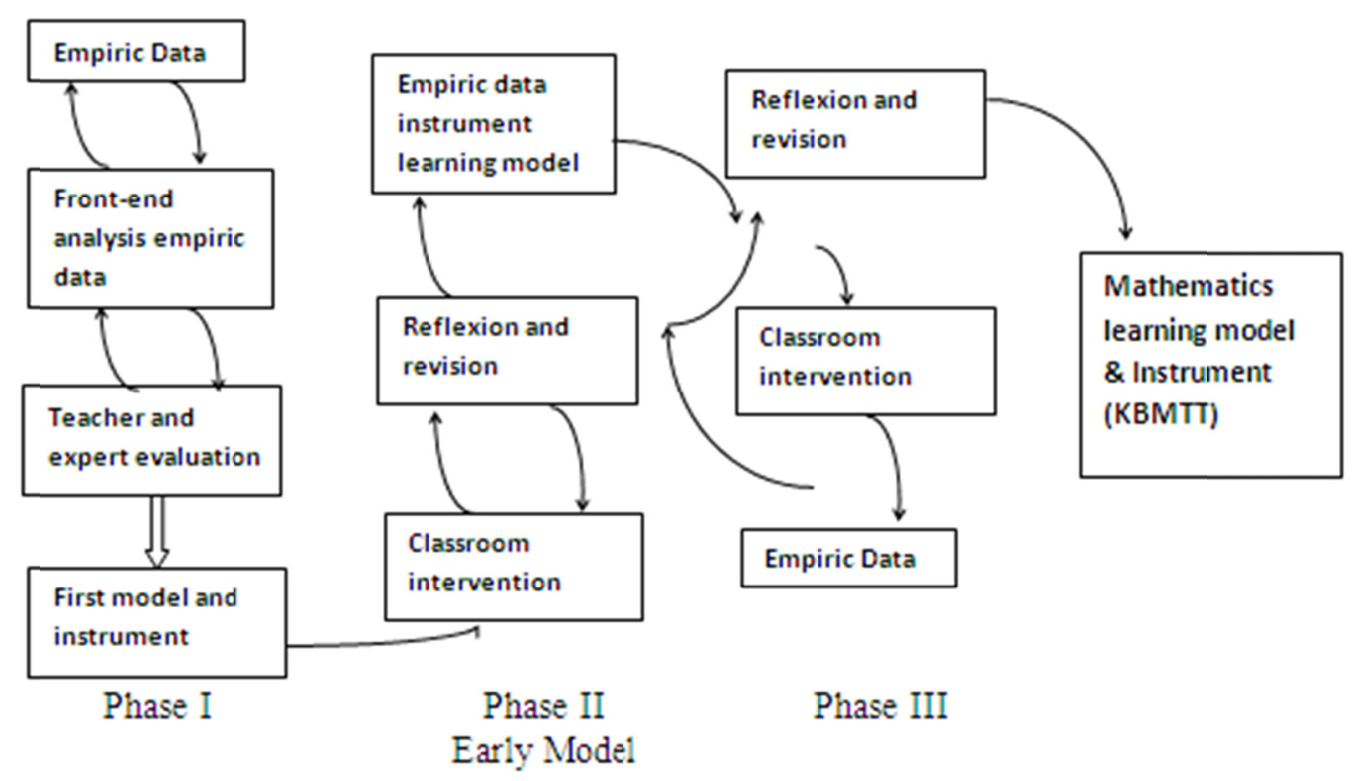

Figure 1. Phases and Activities of Developmental Research

Phase II of this study is referred to Stage Analysis of Formative which aims to develop, analyze, tested, evaluate, and fix the learning model and to validate the instruments of higher order mathematical thinking ability. The model will be tested on sample schools to see its quality (effectiveness and efficiency). The research activities focused on two aspects: (1) analysis the learning process conducted by teachers using the learning model developed at Phase I; (2) analysis and validate the higher order thinking ability instrument. Phase II produces the learning model fix and the valid higher order mathematical thinking ability instrument.

\section{Results and Discussion}

Both learning model and research instruments declared valid by the validator. From the field tests, it is obtained that the validity of higer order mathematical thinking ability is significant at 0.05 and 0.01 level. While the calculation of reliability tests of the five teaching material consisting of Comparison (MAT-1), Arithmetic Social (MAT-2), Triangle (MAT-3), Quadrilateral (MAT-4), and Transformation (MAT-5) respectively scored 0.835; $0.588 ; 0.438 ; 0.833 ; 0.908$. The five materials are presented based on local culture as well as the instrument. Table 1 below shows summary of the results of the instrument test for the five items.

Table 1 . The validity of questions item test high level mathematics thinking

\begin{tabular}{lllllll}
\hline \multicolumn{7}{c}{ Correlations } \\
\hline \multirow{3}{*}{ ITEM_1 } & MAT_1 & MAT_2 & MAT_3 & MAT_4 & MAT_5 \\
\cline { 2 - 7 } & Pearson Correlation & $.775^{* *}$ & $.666^{* *}$ & $.666^{* *}$ & $.700^{* *}$ & $.737^{* *}$ \\
\cline { 2 - 7 } & Sig. (2-tailed) & .000 & .001 & .001 & .000 & .000 \\
\hline & $\mathrm{N}$ & 30 & 20 & 20 & 26 & 30 \\
\hline
\end{tabular}




\begin{tabular}{|c|c|c|c|c|c|c|}
\hline \multirow{3}{*}{ ITEM_2 } & Pearson Correlation & $.707^{* *}$ & $.691^{* *}$ & $.691^{* *}$ & $.786^{* *}$ & $.839^{* *}$ \\
\hline & Sig. (2-tailed) & .000 & .001 & .001 & .000 & .000 \\
\hline & $\mathrm{N}$ & 30 & 20 & 20 & 26 & 30 \\
\hline \multirow{3}{*}{ ITEM_3 } & Pearson Correlation & $.637^{* *}$ & $.588^{* *}$ & $.588^{* *}$ & $.860^{* *}$ & $.739^{* *}$ \\
\hline & Sig. (2-tailed) & .000 & .006 & .006 & .000 & .000 \\
\hline & $\mathrm{N}$ & 30 & 20 & 20 & 26 & 30 \\
\hline \multirow{3}{*}{ ITEM_4 } & Pearson Correlation & $.757^{* *}$ & $.526^{*}$ & $.526^{*}$ & $.789^{* *}$ & $.839^{* *}$ \\
\hline & Sig. (2-tailed) & .000 & .017 & .017 & .000 & .000 \\
\hline & $\mathrm{N}$ & 30 & 20 & 20 & 26 & 30 \\
\hline \multirow{3}{*}{ ITEM_5 } & Pearson Correlation & $.703^{* *}$ & $.455^{*}$ & $.455^{*}$ & $.707^{* *}$ & $.737^{* *}$ \\
\hline & Sig. (2-tailed) & .000 & .044 & .044 & .000 & .000 \\
\hline & $\mathrm{N}$ & 30 & 20 & 20 & 26 & 30 \\
\hline \multirow{3}{*}{ ITEM_6 } & Pearson Correlation & $.686^{* *}$ & $.484^{*}$ & & $.560^{* *}$ & $.839^{* *}$ \\
\hline & Sig. (2-tailed) & .000 & .031 & & .003 & .000 \\
\hline & $\mathrm{N}$ & 30 & 20 & & 26 & 30 \\
\hline \multirow{3}{*}{ ITEM_7 } & Pearson Correlation & $.730^{* *}$ & $.469^{*}$ & & $.632^{* *}$ & $.739^{* *}$ \\
\hline & Sig. (2-tailed) & .000 & .037 & & .001 & .000 \\
\hline & $\mathrm{N}$ & 30 & 20 & & 26 & 30 \\
\hline Cronbach's & Reliability Statistics (R) & 0.835 & 0.588 & 0.438 & 0.833 & 0.908 \\
\hline
\end{tabular}

**. Correlation is significant at the 0.01 level (2-tailed).

*. Correlation is significant at the 0.05 level (2-tailed).

From the aspect of validity, it is obtained that the entire tests designed fulfilled valid criteria with a high level significance. It indicates that the test measure properly what should be measured in accordance with the material taught. Likewise, the calculation results with high reliability, which means that the test will produce the same results (consistent) when performed repeatedly at different times. Thus the test items are eligible to use. The results of this study support the research of Saragih and Napitupulu (2015) previously and in accordance to Arikunto (2013).

One of the test items is as follow.

To get the attention of the visitors, a shop gives discount on one of the traditional music tools Batak Angkola Gordang Sambilan. See the Figure 2 below.
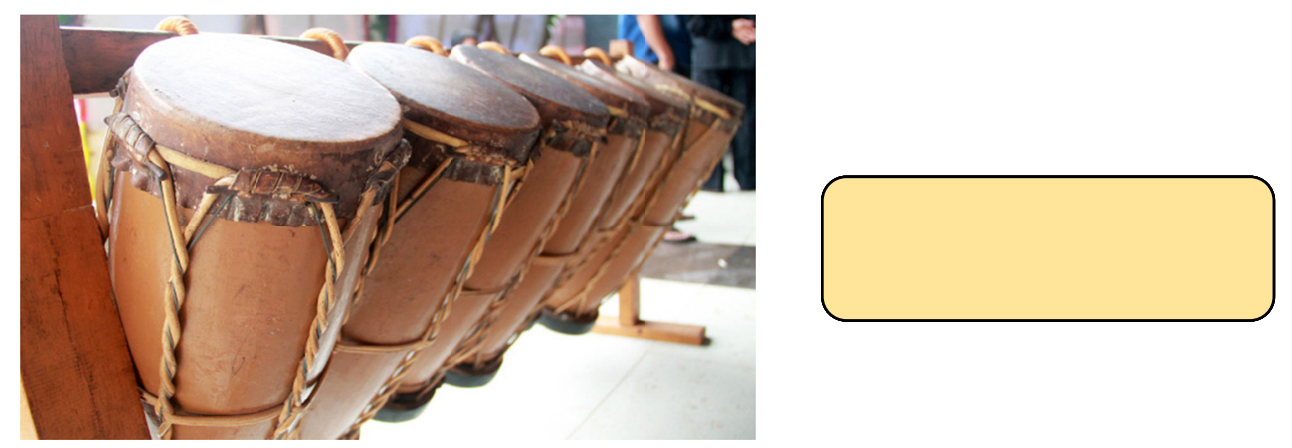

Figure 2. Gordang Sambilan

a. Based on the picture, explain the meaning of Price: 8 Million Rupiahs and Discount $20 \%$.

b. if Mr. Andi want to buy a set of the Gordang Sambilan, make a mathematical model to calculate the amount of the discount. Then compute the price of the music tool after discount.

Most of the students have been able describing the idea or the situation from a picture, able making a mathematical model from the problem given. This showed the existence of positive changes on students' higher order mathematical thinking. Based on observation sheet, result of trial on learning model revealed the enhancement of students' activities. It was seen that they felt freely posing many ideas and it was contributed by 
their understanding on the problems based on local culture given. Similarly based on anquette, they felt enjoy and motivated by the learning process. They did not feel anymore learning mathematics as usual by means of full of pressure and boring with the numbers they faced without any relationship to their daily life.

Particularly, relating to Students' Activities Sheet, it existed some revision among others on social arithmetic and comparison materials. The revision especially on pictures, sentences, design, and context of the local culture used is family relationship in the comparison concept and cultural custom in the trading concept. The engagement of family relationship and the cultural custom in learning process is intended to make interesting and meaningful learning would take place, since they have had knowledge on both. Part of the sheet is presented below.

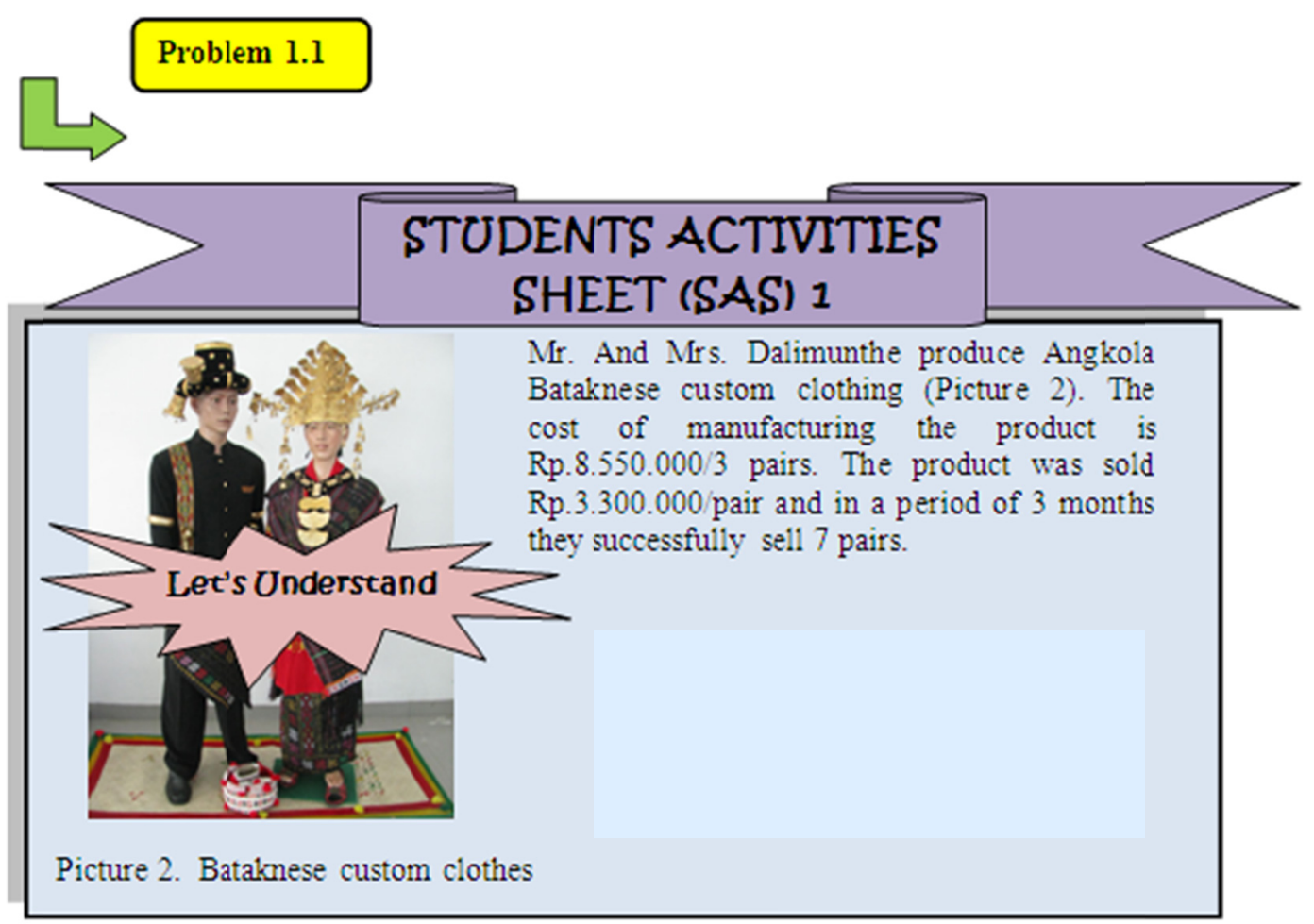

a. What is the cost to produce a pair of the custom?

\section{Answer:}

b. What is the sell price of a pair of the custom?

Answer:

c. Do Mr. and Mrs. Dalimunthe obtain profit or loss? Explain.

Answer: 


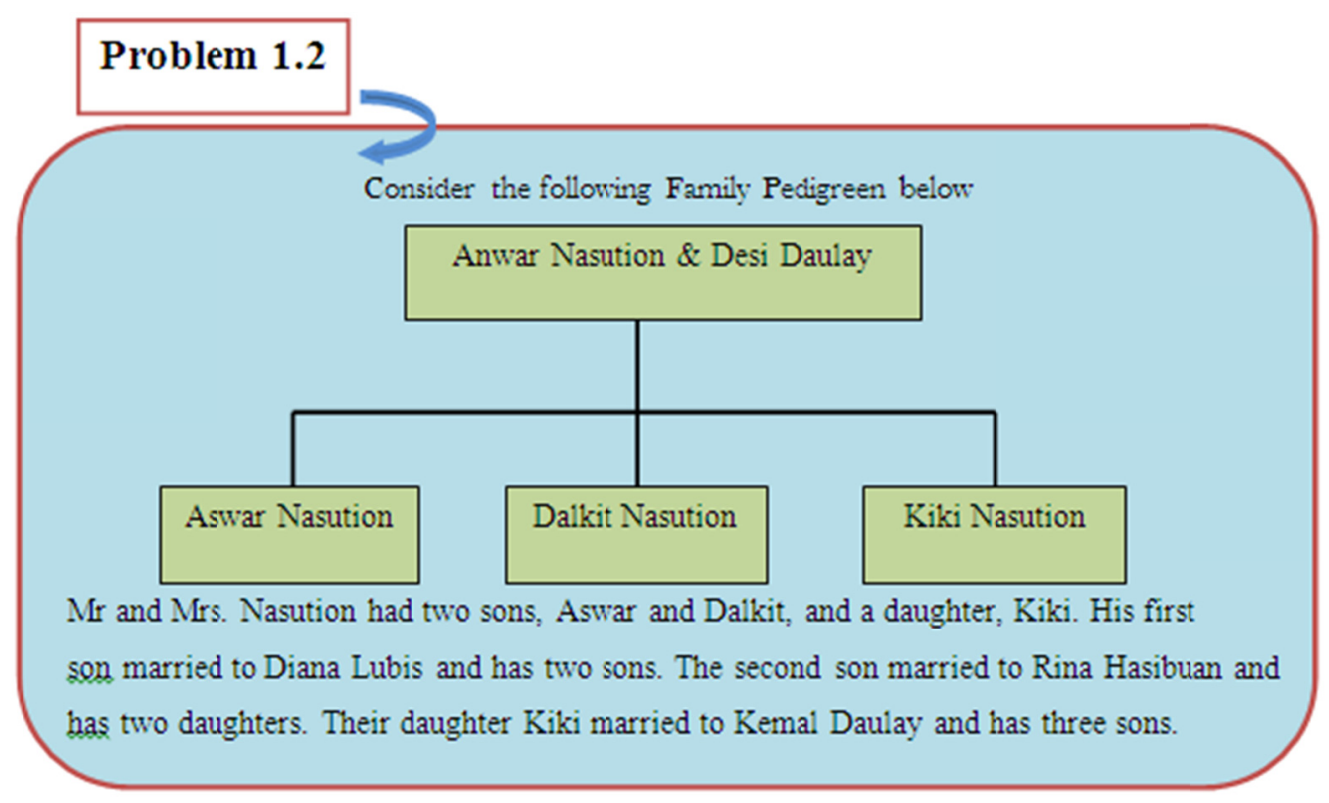

From the above information, determine:

a. The total number of the family with surname Nasution. Explain your answer.

Answer:

b. The number of the family of Daulay's Surname. Explain your answer!

\section{Answer:}

c. Comparison of the amount of the Nasution's surname and Daulay's Surname?

\section{Answer:}

d. Comparison of the amount of man and woman of Nasution's surname.

\section{Answer:}

\section{Based on Problem 1.1 and 1.2}

a. Explain the meaning of comparison?

b. Explain the meaning ratio? 
Learning devices, especially LAS is very important and vital in learning process. For LAS contains concepts or material that will be taught should be able be digested well by students individually or in groups. Changes in the context of the problem designed in LAS aim to make it easier for students to understand the concepts being studied, and in accordance with the focus of this study, the local cultural context with the local cultural environment in the learning process is expected such that meaningful learning takes place. This is in accordance to Trianto (2011) and Saragih (2015) which states that the process of meaningful learning can occur if concepts that will be studied is associated with other conditions. Opinions not much different proposed by Davis (1996) that in the process of learning new information must be associated with past experiences through a logical framework that transform, organize, and interpret experiences and knowledge built in the mind through the process of assimilation and accommodation. The process of assimilation or accommodation is not separated from the significance of the learning process

The presence of the local cultural context in mathematics learning should be on the agenda for a mathematics teacher. This is in line with Bishop (Tandililing, 2013) which says that mathematics is a form of culture that integrates all aspects of people's lives wherever they may be. The connection of mathematics with culture was also stated by Pinxten (Tandililing, 2013). He states that the essence of mathematics is symbolic technology that grows on the skill or activity which is cultural. Thus the presence of local cultural context in mathematics learning endorses meaningful learning process occurs as expected.

The development of learning model based on local culture mentioned above supported the previous results (Yusra \& Saragaih, 2016). The writers developed joyful learning model based on Malay culture. Similar results were reported by Mahrani and Saragi (2016) and Hutagalung (2016). The first researchers developed problem-based learning with problems designed based on Aceh culture, while the second developed guided-discovery learning based on Batak Toba culture.

When viewed from the aspect of learning, the overall study discussed above used student-centered learning approach with local culture-based. It indicates that the active role of students which is claimed as an obstacle has been developed. Similarly, an environmental factor such as local cultural context is able to provide a positive impact on the development of students. As it was explained previously that the student-centered learning based on local culture endorses learning process becomes meaningful.

According Saragih $(2009,2010,2015)$, the views of student-centered learning and meaningful learning is very close to the core of constructivism. This was confirmed by Suparno (1997), that the principles constructivism is, (a) the knowledge built by students actively, (b) focused in learning process lies in part of students, (c) to teach is to help students to learn, (d) the learning is more emphasized on the process not the end result, (e) teacher is a facilitator.

Teacher as facilitator demands the role of teacher is no longer as source of information, but rather provide learning resources such as preparing teaching materials (SAS), media, visual aids, and managing classroom either students learn individually or in groups. Certainly it should be designed before the learning process starts. As previously explained, preparing teaching materials (SAS) need to pay attention to students' everyday environment or culture. It should encourage students more actively involved individually or in groups in the learning process, especially in observing, investigating, drawing conclusions from the given data, or create hypotheses. This enable students' creativity, skills and abilities develop. Mathematical concepts understanding achieved through a learning process involving the daily or local culture of students believed learning to be more meaningful.

While in classroom management students work in groups are needed such that they interact positively each other in constructing mathematical concepts. This is in line with Vygotsky (Suharta, 2004; Suparno 1997), that knowledge construction which regards social environment called social constructivism can be formed individually and socially, so that the study groups can be developed. According to Von Glasersfeld (Suparno, 1997), the study group should reveal how he sees the problem and what he should do to overcome it, this means that students have to reflect on what they think.

There are two important concepts in the theory of Vygotsky (Slavin, 1997; Suharta, 2004), namely Zone of Proximal Development and Scaffolding. According Zulfikri (2008) Zone of Proximal Development is the development gap between actual and potential development, where between whether a child can do anything without the help of an adult and whether a child can do with the direction of an adult or collaboration with peers. Meanwhile, according Prayudi 2008) scaffolding is to give a child a number of great assistance during the early stages of learning and then reduce the effort and provide the opportunity for the child to take over increasing responsibility as soon as he be able to do himself. Therefore, based on the underlying concept, it is reasonable to 
expect an improvement in higher order mathematical thinking skills of junior high school students who taught using student-centered learning model which based on local culture.

\section{Conclusion}

Based on the results of the study, it is concluded that:

1) Results of the trial on higher order mathematical thinking test instrument which consists of five teaching materials namely Comparison (MAT-1), Social Arithmetic (MAT-2), Triangle (MAT-3), Quadrilateral (MAT-4), and transformation (MAT-5) showed each having reliability value respectively $0.835 ; 0.588$; $0.438 ; 0.833 ; 0.908$ with significant validity at the level of 0.05 and 0.01 .

2) The trial of student-centered learning model based on local culture showed that the model is effective to use in the teaching and learning mathematics for junior high school students.

\section{Suggestion}

The study suggests:

1) To mathematics teacher, to improving accuracy, consistency, as well as the effectiveness of learning and the students' answers to the problems of mathematical thinking skills, especially higher order mathematical thinking, teachers should first conduct trials on the tests and the learning devices before using them.

2) The mathematics teacher is expected to implement student-centered learning model based on local culture as an alternative model in the teaching and learning mathematics in junior high school. Therefore, it is suggested that schools develop the model as an effective one to other topics in mathematics or beyond.

3) Principals and schools are expected to be open and receptive to effective learning model innovations one of which is a student-centered learning model based on local culture.

\section{References}

Arikunto, S. (2012). Dasar-Dasar Evaluasi Pendidikan Edisi 2. Jakarta: Bumi Aksara.

Haji, S. (2005). Pengaruh Pendekatan Matematika Realistik terhadap Hasil Belajar Matematika di Sekolah Dasar. Disertasi Doktor pada PPS UPI: Tidak Diterbitkan.

Herman, T. (2006). Pembelajaran Berbasis Masalah untuk Meningkatkan Kemampuan Berpikir Matematis Tingkat Tinggi Siswa Sekolah Menengah Pertama (SMP). Disertasi Doktor pada PPS UPI: Tidak Diterbitkan.

Mahrani A. (2016). Pengembangan Perangkat Pembelajaran melalui Model Pembelajaran Berbasis Masalah Berdasarkan Konteks Budaya Aceh untuk Meningkatkan Kemampuan Komunikasi Matematik dan Keterampilan Sosial Siswa SMPN 1 Muara Batu. Tesis, Tesis Program Studi Pendidikan Matematika Pascasarjana Universitas Negeri Medan: tidak diterbitkan.

National Council of Teacher of Mathematics. (2000). Principles and Standards for School Mathematics. Reston, VA: NCTM.

Prayudi. (2008). Perkembangan Anak menurut Jean Piaget dan Viygotsky. Retrieved from http://prayudi.wordpress.com

Saragih, S. (2007). Mengembangkan Kemampuan Berpikir Logis dan Komunikasi Matematik Siswa Sekolah Menengah Pertama melalui Pendekatan Matematika Realistik. Disertasi Doktor pada PPS UPI: Tidak Diterbitkan.

Saragih, S. (2009). Pengembangan Berpikir Matematika Tingkat Tinggi Siswa SMP melalui Pendekatan Matematika Realistik. Laporan Penelitian Hibah Bersaing Tahun I. Unimed, Medan.

Saragih, S. (2010). Pengembangan Berpikir Matematika Tingkat Tinggi Siswa SMP melalui Pendekatan Matematika Realistik. Laporan Penelitian Hibah Bersaing Tahun II. Unimed, Medan.

Saragih, S. (2013). Pengembangan Model Pembelajaran Berpusat Pada Siswa Untuk meningkatkan Kemampuan Matematika Tingkat Tinggi. Laporan Penelitian Hibah Pasca, Tahun Pertama. Unimed, Medan.

Saragih, S. (2015). Pengembangan Model Pembelajaran Berpusat Pada Siswa Berbasi Budaya Lokal Untuk meningkatkan Kemampuan Matematika Tingkat Tinggi. Laporan Penelitian Hibah Pasca, Tahun Pertama. Unimed, Medan.

Saragih, S., \& Napitupulu, E. (2015). Developing Student-Centered Learning Model to Improve High Order Mathematical Thinking Ability. International Education Studies, 8(6), 104-112. 
https://doi.org/10.5539/ies.v8n6p104

Saragih, S., \& Habeahan, W. L. (2014). The improving of Problem Solving Ability and Students' Creativity Mathematical by Using Problem Based Learning in SMP Negeri 2 Siantar, Journal of Education and Practice, 5(35), 123-132.

Sugiyono. (2010). Metode Penelitian Kuantitatif Kualitatif dan $R \& D$. Bandung :Alfabeta

Sumarmo, U. (2002). Alternatif Pembelajaran Matematika dalam Menerapkan Kurikulum Berbasis Kompetensi. Makalah pada Seminar Tingkat Nasional FPMIPA UPI: Tidak Diterbitkan.

Sumarmo, U. (2005). Pengembangan Berfikir Matematik Tingkat Tinggi Siswa SLTP dan SMU serta Mahasiswa Strata Satu (S1) melalui Berbagai Pendekatan Pembelajaran. Laporan Penelitian Lemlit UPI: Tidak Diterbitkan.

Suparno, P. (1997). Filsafat Konstruktivisme dalam Pendidikan. Yogyakarta: Kanisius.

Tandililing, E. (2013). Pengembangan Pembelajaran Matematika Sekolah dengan Pendekatan Etnomatematika Berbasis Budaya Lokal Sebagai Upaya Untuk Meningkatkan Kualitas Pembelajaran Matematika di Sekolah. Prosiding.

Trianto. (2011). Mendesain Model Pembelajaran Inovatif-Progresif. Jakarta: Kencana.

Yuliani, K., \& Saragih, S. (2015). The Development of Learning Devices Based Guided Discovery Model to Improve Understanding Concept and Critical Thinking Mathematically Ability of Students at Islamic Junior High School of Medan. Journal of Education and Practice, IISTE, 6(24).

Yusra, D. A., \& Saragih, S. (2016). The Profile of Communication Mathematics and Students' Motivation by Joyful Learning-Based Learning Context Malay Culture. British Journal of Educaton, Society \& Behavioural Science, 15(4) 1-16. https://doi.org/10.9734/BJESBS/2016/25521

Zulfikri. (2008). Teori Perkembangan Kognitif Vygotsky. Retrieved from http://valmband.multiply.com

\section{Copyrights}

Copyright for this article is retained by the author(s), with first publication rights granted to the journal.

This is an open-access article distributed under the terms and conditions of the Creative Commons Attribution license (http://creativecommons.org/licenses/by/4.0/). 